\title{
Glycophenotype of breast and prostate cancer stem cells treated with thieno[2,3-b]pyridine anticancer compound
}

This article was published in the following Dove Press journal:

Drug Design, Development and Therapy

14 March 2017

Number of times this article has been viewed

\author{
Angela Mastelić \\ Vedrana Čikeš Čulićl \\ Nikolina Režić Mužinić' \\ Milena Vuica-Ross ${ }^{2}$ \\ David Barker ${ }^{3}$ \\ Euphemia Y Leung ${ }^{4,5}$ \\ Jóhannes Reynisson ${ }^{3}$ \\ Anita Markotićl
}

'Department of Medical Chemistry and Biochemistry, University of Split School of Medicine, Split, Croatia; 'Department of Pathology, Johns Hopkins School of Medicine, Baltimore, MD, USA; ${ }^{3}$ School of Chemical Sciences, The University of Auckland, ${ }^{4}$ Auckland Cancer Society Research Centre, The University of Auckland, ${ }^{5}$ Molecular Medicine and Pathology Department, The University of Auckland, Auckland, New Zealand

Correspondence: Anita Markotić Department of Medical Chemistry and Biochemistry, University of Split School of Medicine, Šoltanska 2, 21000 Split, Croatia

Tel/fax +385 2l 557870

Email anita.markotic@mefst.hr

Jóhannes Reynisson

School of Chemical Sciences, The University of Auckland, Private Bag 92019, Auckland II42, New Zealand Tel +6493737599 ext 83746

Fax +6493737422

Email j.reynisson@auckland.ac.nz
Abstract: Tumor progression may be driven by a small subpopulation of cancer stem cells (CSCs characterized by CD44 $/ \mathrm{CD} 24^{-}$phenotype). We investigated the influence of a newly developed thienopyridine anticancer compound (3-amino-5-oxo- $N$-naphthyl-5,6,7, 8-tetrahydrothieno[2,3-b]quinoline-2-carboxamide, 1) on the growth, survival and glycophenotype (CD15s and GM3 containing neuraminic acid substituted with acetyl residue, NeuAc) of breast and prostate cancer stem/progenitor-like cell population. MDA-MB-231 and Du-145 cells were incubated with compound $\mathbf{1}$ alone or in combination with paclitaxel. The cellular metabolic activity was determined by the 3-(4,5-dimethylthiazolyl-2)-2,5-diphenyltetrazolium bromide (MTT) assay. The type of cell death induced by 48-h treatment was assessed using a combination of Annexin-V-FITC and propidium iodide staining. Flow cytometric analysis was performed to detect the percentage of $\mathrm{CD} 44^{+} / \mathrm{CD} 24^{-}$cells, and $\mathrm{GM} 3$ and $\mathrm{CD} 15$ s positive CSCs, as well as the expression of GM3 and CD15s per one CSC, in both cell lines. Compound 1 produces a dose- and time-dependent cytotoxicity, mediated mainly by apoptosis in breast cancer cells, and slightly (2.3\%) but statistically significant lowering breast CSC subpopulation. GM3 expression per one breast CSC was increased, and the percentage of prostate $\mathrm{GM}^{+} \mathrm{CSC}$ subpopulation was decreased in cells treated with compound $\mathbf{1}$ compared with non-treated cells. The percentage of CD15 $\mathrm{s}^{+}$CSCs was lower in both cell lines after treatment with compound $\mathbf{1}$. Considering that triple-negative breast cancers are characterized by an increased percentage of breast CSCs and knowing their association with an increased risk of metastasis and mortality, compound $\mathbf{1}$ is a potentially effective drug for triple-negative breast cancer treatment.

Keywords: breast, prostate, cancer stem cells, CD44+CD24- ${ }^{-}$, GM3, CD15s

\section{Introduction}

Metastasis, tumor recurrence and resistance to therapy are the leading causes of death for patients with prostate and breast cancer. Tumor progression may be driven by cancer stem cells (CSCs) that have the ability to self-renew and to regenerate the primary tumor phenotypic heterogeneity. ${ }^{1,2}$ The $\mathrm{CD} 44^{+} / \mathrm{CD} 24^{-}$phenotype defines the subpopulation of cancer cells with stem-like qualities. ${ }^{3}$ It is believed that CD $44^{+} / \mathrm{CD} 24^{-}$ CSCs are involved in therapy resistance in various cancers, including triple-negative breast cancer (breast cancer that does not express the genes for estrogen receptor, progesterone receptor and the human epidermal growth factor receptor-2) and prostate cancer. ${ }^{1,2}$ Treatment of triple-negative breast cancers with cytotoxic chemotherapeutic such as paclitaxel shows only $21 \%$ of pathologic complete response rate in the breast and axilla. ${ }^{4}$ Prostate cancer exhibits high intrinsic drug resistance with sensitivity to few chemotherapeutics once androgen deprivation fails. ${ }^{5}$ 
MDA-MB-231 (a triple-negative breast cancer) ${ }^{6}$ and Du-145 (androgen-independent prostate cancer) ${ }^{7}$ cell lines contain large amount of GM3 ganglioside. GM3 is the simplest acidic glycosphingolipid, containing $N$-acetyl neuraminic (NeuAc) or N-glycolylneuraminic acid (NeuGc). GM3 (NeuGc) ganglioside is especially interesting in breast cancer immunotherapy with highly specific anti-GM3 (NeuGc) ganglioside monoclonal antibody due to its restrictive expression in normal human tissues. ${ }^{8}$ GM3 (NeuAc) is known as a marker of the membrane microdomains called lipid rafts. Lipid rafts are functional units in cell membranes, biochemically characterized as detergent insoluble, ${ }^{9}$ involved in many immune signal transduction processes, ${ }^{10}$ including CD44 and endothelial selectin-mediated neutrophil signaling. ${ }^{11,12}$ Glycoprotein CD44 and CD15s (sialyl-Lewis x) on cancer cells enable malignant infiltration in different tissues. ${ }^{13}$ A novel mechanism of regulating breast cancer cell migration involves palmitoylation-dependent alterations in the lipid raft affiliation of CD44. ${ }^{14}$ Minor changes in lipid raft GM3 (NeuAc) content can cause dramatic changes in protein structure and activity. In the case of insulin resistance, enhanced GM3 lipid raft content disturbs insulin receptor function. ${ }^{15}$ In our study, the change in number of GM3 molecules per one cell after the drug treatment, expressed as GM3 geometric mean fluorescence intensity (GMI), would indicate the possible involvement of disturbed GM3 lipid raft content in the cytotoxic effects of thieno[2,3- $b]$ pyridine inhibitors.

Knowing that targeting of the CSC population is a promising approach to overcome tumor relapse and resistance, the aim of this study was to determine the percentage of CSCs after treatment with newly synthesized thieno[2,3-b]pyridine anticancer agent. ${ }^{16}$ It is now established that this class of thieno[2,3-b]pyridines has potent anticancer activity against a variety of tumor cell lines. ${ }^{17-19}$ The molecular structure of compound $\mathbf{1}$ used in this study is shown in Figure 1. The efficacy of the thieno[2,3- $b$ ]pyridines was discovered by virtual high-throughput screen (vHTS) against the phospholipase C- $\gamma 2$ (PLC- $\gamma 2$ ) isoform. ${ }^{20}$ The administration of thieno[2,3- $b$ ] pyridines causes the breast cancer cell line MDA-MB-231 to be severely growth restricted, rounded and blebbing of the plasma membrane, $\mathrm{G}_{2} / \mathrm{M}$ phase population increase in the cell cycle and decrease in motility as reflected in slowed proliferation in scratch assays. ${ }^{21}$ These effects on MDAMB-231 are more in line with the inhibition of the PLC- $\delta 1$ and $\delta 2$ isoforms making them the most plausible target for this class of compounds. ${ }^{21}$ However, it is quite possible that other biomolecular targets are affected, contributing to the overall efficacy of the thieno[2,3-b]pyridines, for example, tyrosyl-DNA phosphodiesterase I. ${ }^{22}$

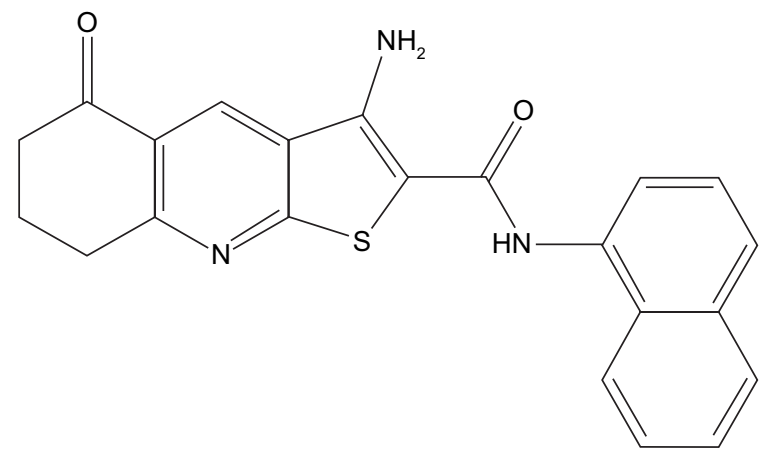

Figure I The structure of the newly synthesized anticancer agent (compound I). Note: Compound I, 3-amino-5-oxo-N-naphthyl-5,6,7,8-tetrahydrothieno[2,3-b] quinoline-2-carboxamide.

In this study, cell metabolism after administration of derivative $\mathbf{1}$ alone and in combination with paclitaxel was assessed by MTT assays. Flow cytometry was used to determine CD44, CD24, CD15s and GM3 (NeuAc) expression, as well as early and late apoptosis and necrosis (AnnexinV-FITC and propidium iodide staining).

\section{Materials and methods Chemistry}

3-Amino-5-oxo- $N$-naphthyl-5,6,7,8-tetrahydrothieno[2,3-b] quinoline-2-carboxamide (1) (Figure 1) was dissolved in DMSO. Compound 1 has a reported growth inhibition at $50 \%\left(\mathrm{GI}_{50}\right)$ at $298 \mathrm{nM}$ for MDA-MB-231 and $327 \mathrm{nM}$ for Du-145, and a total growth inhibition (TGI) of $4.1 \mu \mathrm{M}$ for MDA-MB-231 and $6.7 \mu \mathrm{M}$ for Du-145 using the sulforhodamine B assay. ${ }^{19}$ Furthermore, the concentration of an inhibitor $\left(\mathrm{IC}_{50}\right)$ value for MDA-MB-231 is reported to be $690 \mathrm{nM}$ using the thymidine uptake assay. ${ }^{21}$

\section{Cell lines}

Cancer cell lines were grown in a humidified incubator at $37^{\circ} \mathrm{C}$ and $5 \% \mathrm{CO}_{2}$ in DMEM (for MDA-MB-231 cells; Sigma-Aldrich, Steinheim, Germany) and in RPMI-1640 media (for Du-145 cells; EuroClone, Milan, Italy) containing $10 \%$ fetal bovine serum (EuroClone) and $1 \%$ antibiotics (EuroClone). According to the provisions of Article 16 of the School of Medicine in Split Code of Ethics, the Committee decided that the research in question is in accordance with the provisions of the Code of Ethics which regulate research on human subjects in scientific, research and professional work and with the ethical principles of Declaration of Helsinki.

\section{Cytotoxic activity assay}

Cell viability was determined by measured cell metabolism using a MTT assay. ${ }^{23}$ An equal numbers of cells $\left(10^{4}\right.$ cells $\left./ 100 \mu \mathrm{L}\right)$ were plated in three replicates and allowed 
to attach overnight. Cells were then treated with complete media or individual solutions of compound $\mathbf{1}$ at $0.5,1,5$, 10 and $25 \mu \mathrm{M}$ in complete media, in triplicate, for 4,24 , 48 and 72 h. The same compound 1 concentrations were tested in combination with paclitaxel. The concentration of paclitaxel was $40 \mathrm{nM}$ for MDA-MB-231 and $12 \mathrm{nM}$ for Du-145 cells. ${ }^{24,25}$ Following treatment, cells were incubated with $0.5 \mathrm{mg} / \mathrm{mL}$ MTT in media for $1 \mathrm{~h}$, and then the media were removed and DMSO was added. Absorbance was measured at $570 \mathrm{~nm}$ (signal) and $690 \mathrm{~nm}$ (background).

\section{Flow cytometric analysis}

An equal numbers of cells $\left(5 \times 10^{5}\right)$ were seeded in six-well plates and treated with $2 \mu \mathrm{M}$ compound 1 and/or paclitaxel for $48 \mathrm{~h}$ and then analyzed for apoptosis. A combination of Annexin-V-FITC and propidium iodide staining allows the distinction between early (Annexin- $\mathrm{V}^{+} / \mathrm{PI}^{-}$) and late (Annexin- $\mathrm{V}^{+} / \mathrm{PI}^{+}$) apoptotic cells, necrotic cells and live cells. After treatment with compound 1, paclitaxel or their combination, the cells were trypsinized, washed with phosphate-buffered saline (PBS) and resuspended in $100 \mu \mathrm{L}$ of the binding buffer containing $5 \mu \mathrm{L}$ Annexin-VFITC and/or $5 \mu \mathrm{L}$ of propidium iodide (Annexin-V-FITC Apoptosis Detection Kit I; BD Biosciences). The cells were incubated for $15 \mathrm{~min}$ at room temperature in the dark and thereafter analyzed by flow cytometry (BD Accuri C6; BD Biosciences). The percentages of apoptotic cells (Annexin-V-positive cells) were analyzed using the FlowLogic Software (Inivai) and presented as mean \pm standard deviation (SD).

In addition, cells treated with compound $\mathbf{1}$ and/or paclitaxel for $48 \mathrm{~h}$, as well as the controls, were trypsinized and washed with PBS. Cells were pretreated with an Fc receptorblocking reagent (Miltenyi Biotec $\mathrm{GmbH}$, Bergisch Gladbach, Germany) to prevent nonspecific binding. After 15 min of incubation with diluted anti-CD15s (BD Biosciences) at room temperature, cells were incubated with diluted anti-CD44FITC (BD Biosciences), anti-CD24-PE (eBioscience, Inc., San Diego, CA, USA) and secondary antibody conjugated with eFluor 660 fluorochrome (eBioscience, Inc.) for $15 \mathrm{~min}$ in the dark, resuspended in PBS and thereafter analyzed by flow cytometry (BD Accuri C6; BD Biosciences). The procedure for determination of GM3 was the same with the exception of incubation with anti-GM3 (NeuAc; Cosmo Bio Co, Tokyo, Japan) instead of anti-CD15s. Antibodies were diluted (Table S1).

Data acquisition of triple-stained samples was performed on a BD Accuri 6 cytometer and analyzed using the FlowLogic Software. CD $44^{+}$cells were gated, and
CSCs were determined. GM3 and CD15s were determined on CSCs.

\section{Statistical analysis}

For statistical analyses, one-way ANOVA followed by post-hoc Tukey test was performed using statistical software Statistica for Windows version 7.0 (Stat Soft, Tulsa, OK, USA) with the significance set at $P<0.05$.

\section{Results}

\section{Compound I produces a dose- and time- dependent cytotoxicity}

In this study, we compared cell viability after 4, 24, 48 and $72 \mathrm{~h}$ of treatment with compound $\mathbf{1}$ using the MTT assay (Figure 2).

$\mathrm{IC}_{50}$ value for MDA-MB-231 cells was $10.9,9.5$, and $6.7 \mu \mathrm{M}$ after 24,48 and $72 \mathrm{~h}$ of treatment, respectively. $\mathrm{IC}_{50}$ value for Du-145 cells was 5.1 $\mu \mathrm{M}$ after 72-h treatment.

Dose- and time-dependent growth retardation was regular for MDA-MB-231 cells. After 4-h treatment with only $25 \mu \mathrm{M}$ compound 1 showed significant effect on decrease in cell viability as compared to non-treated cells (100\% of viability, cell survival $=1$, Figure 2 ). At $24 \mathrm{~h}$, there was a significant decrease in cell viability with $5 \mu \mathrm{M}$ of compound $\mathbf{1}$, and after $48 \mathrm{~h}$ with as little as $1 \mu \mathrm{M}$ of compound 1 (Figure 2A).

After $4 \mathrm{~h}$, treatment with 10 and $25 \mu \mathrm{M}$ compound 1 showed a significant decrease in Du-145 cell viability compared with non-treated cells $(100 \%$ of viability, cell survival $=1$, Figure 2C). Du-145 cells showed similar growth after $24 \mathrm{~h}$ as MDA-MB-231 cells with the exception of treatment with $25 \mu \mathrm{M}$ compound 1 . This may be due to poor water solubility of compound 1. At higher concentrations, it might be forming a suspension, which lowers the active concentration of the compound in the solution.

After 48 and $72 \mathrm{~h}$, lower concentrations of compound $\mathbf{1}$ were more cytotoxic to Du-145 in comparison to MDA-MB231 cells (Figure 2C).

MTT assay was also performed after paclitaxel treatment and after combined treatment with paclitaxel and a dilution curve $(0.5-25 \mu \mathrm{M})$ of compound $\mathbf{1}$. The combination of paclitaxel with $0.5,1$ and $5 \mu \mathrm{M}$ compound 1 showed a decrease in cell survival of MDA-MB-231 cells after $4 \mathrm{~h}$. After $24 \mathrm{~h}$, a significant decrease was noticed after treatment with $1 \mu \mathrm{M}$ compound 1 and paclitaxel for MDA-MB-231 cells and at 10 and $25 \mu \mathrm{M}$ compound 1 and paclitaxel for Du-145 cells. In MDA-MB-231 cell line, paclitaxel in combination with higher compound $\mathbf{1}$ concentrations showed antagonistic effect, that is, increased cell survival. Possible antagonistic effects could be caused by changed glycosphingolipid 
GM3 expression after PLC inhibitor treatment as it will be discussed. Results showing decreased cell survival were significant for $0.5-25 \mu \mathrm{M}$ compound $\mathbf{1}$ and paclitaxel treatment after 48 and $72 \mathrm{~h}$ for both cell lines. In this combined treatment, regular concentration/cytotoxicity relationship was lost for both cell lines. Lower concentrations $(0.5-1 \mu \mathrm{M})$ of compound 1 were more effective if combined with paclitaxel (Figure 2B and D). With this result, we decided to test the type of cell death and to determine CSC glycophenotype using $2 \mu \mathrm{M}$ compound $\mathbf{1}$.
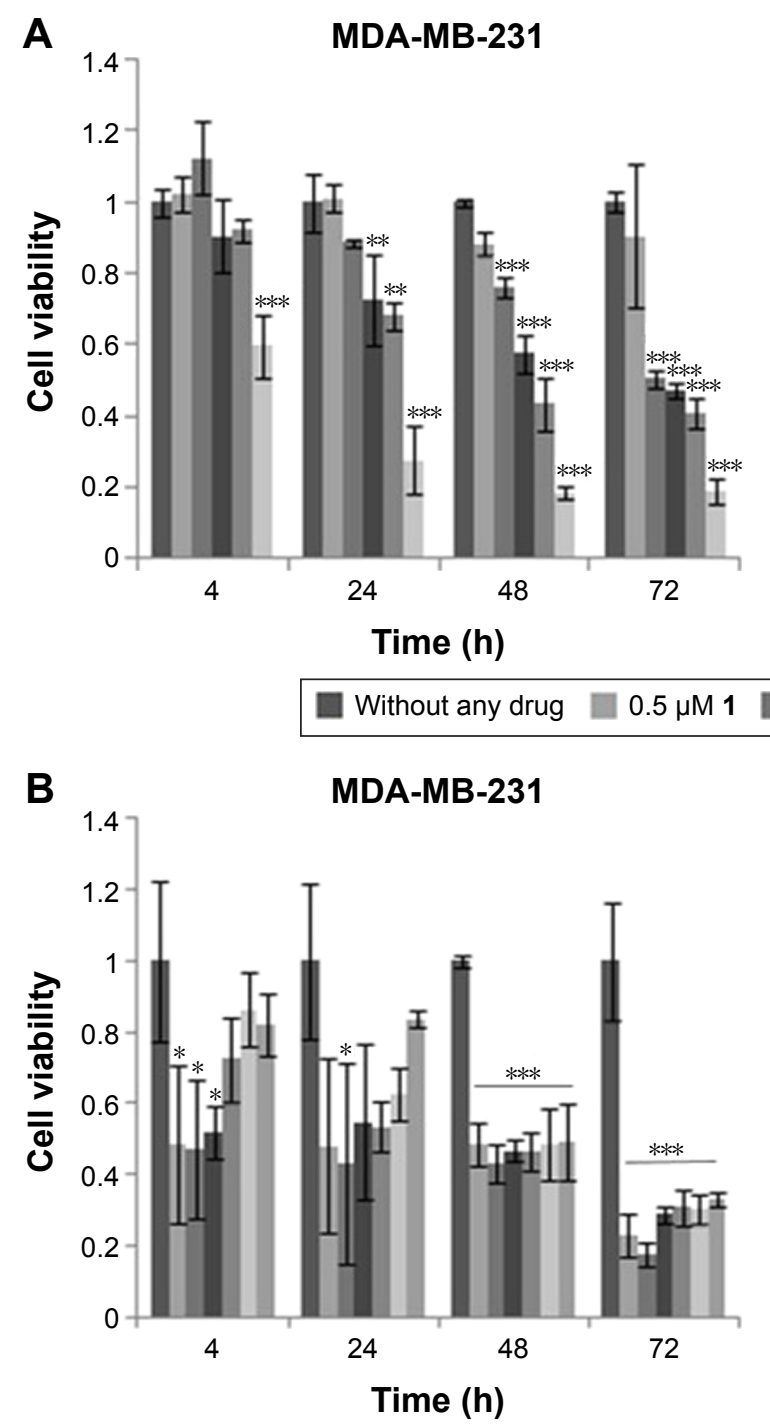

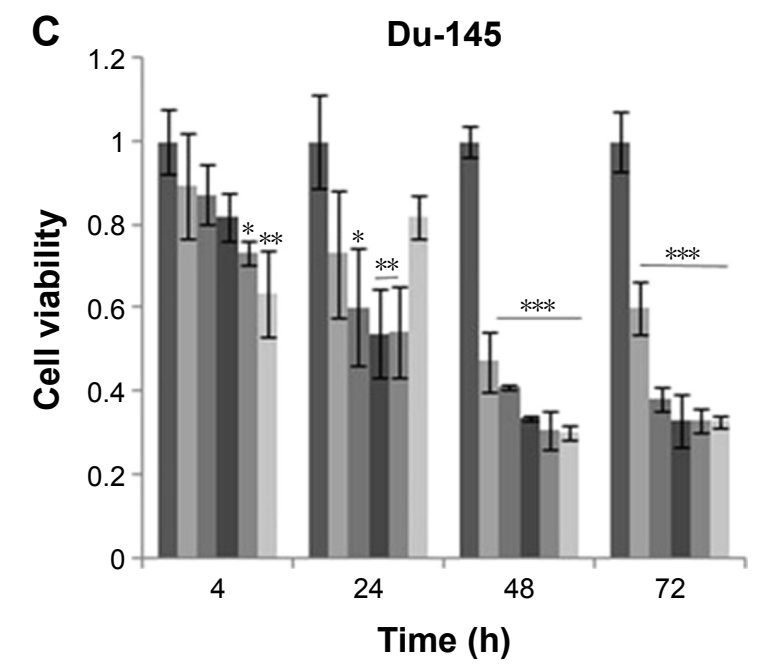

Compound I-induced cell death of breast CSCs occurs mainly by apoptosis

To determine whether the MTT findings are due to cell death or cell cycle arrest, we subsequently determined the type of cell death induced by 48 -h treatment with $2 \mu \mathrm{M}$ compound 1 and/or paclitaxel (40 $\mathrm{nM}$ for breast and $12 \mathrm{nM}$ for prostate cancer cells). ${ }^{24,25}$ The majority of cells from both cell lines died by treatment-induced apoptosis (Figure 3 ). Compound $\mathbf{1}$ alone showed significant increase in early apoptosis in MDA-MB231 cells compared with non-treated cells. The percentage of

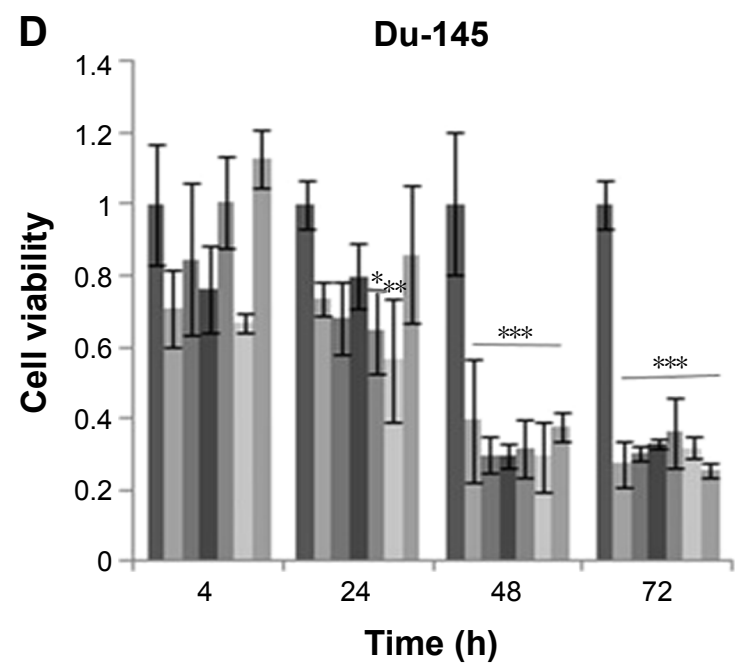

\begin{tabular}{|c|c|c|c|}
\hline Without any drug & $0.5 \mu \mathrm{M} 1+$ paclitaxel & $1 \mu \mathrm{M} 1+$ paclitaxel & $5 \mu \mathrm{M} 1+$ paclitaxel \\
\hline $10 \mu \mathrm{M} 1+$ paclitaxel & $25 \mu \mathrm{M} 1+$ paclitaxel & Paclitaxel & \\
\hline
\end{tabular}

Figure 2 Cell viability after drug treatment.

Notes: Compound I produces a dose- and time-dependent metabolic defect in MDA-MB-23I cell line (A). Cells were treated with a dose-dependent curve of I as shown in the figure for 4, 24, 48 and $72 \mathrm{~h}$ and cell metabolism evaluated by the MTT assay (A, C). Metabolic defect is augmented in combination of compound I with 40 and 12 $\mathrm{nM}$ paclitaxel for MDA-MB-23I (B) and Du-I45 (D) cell line, respectively. Data represent the mean \pm SD. Columns, mean of viable cells; bars, SD; $* P<0.05$; $* * P<0.0$ I; $* * * P<0.001$.

Abbreviation: SD, standard deviation. 

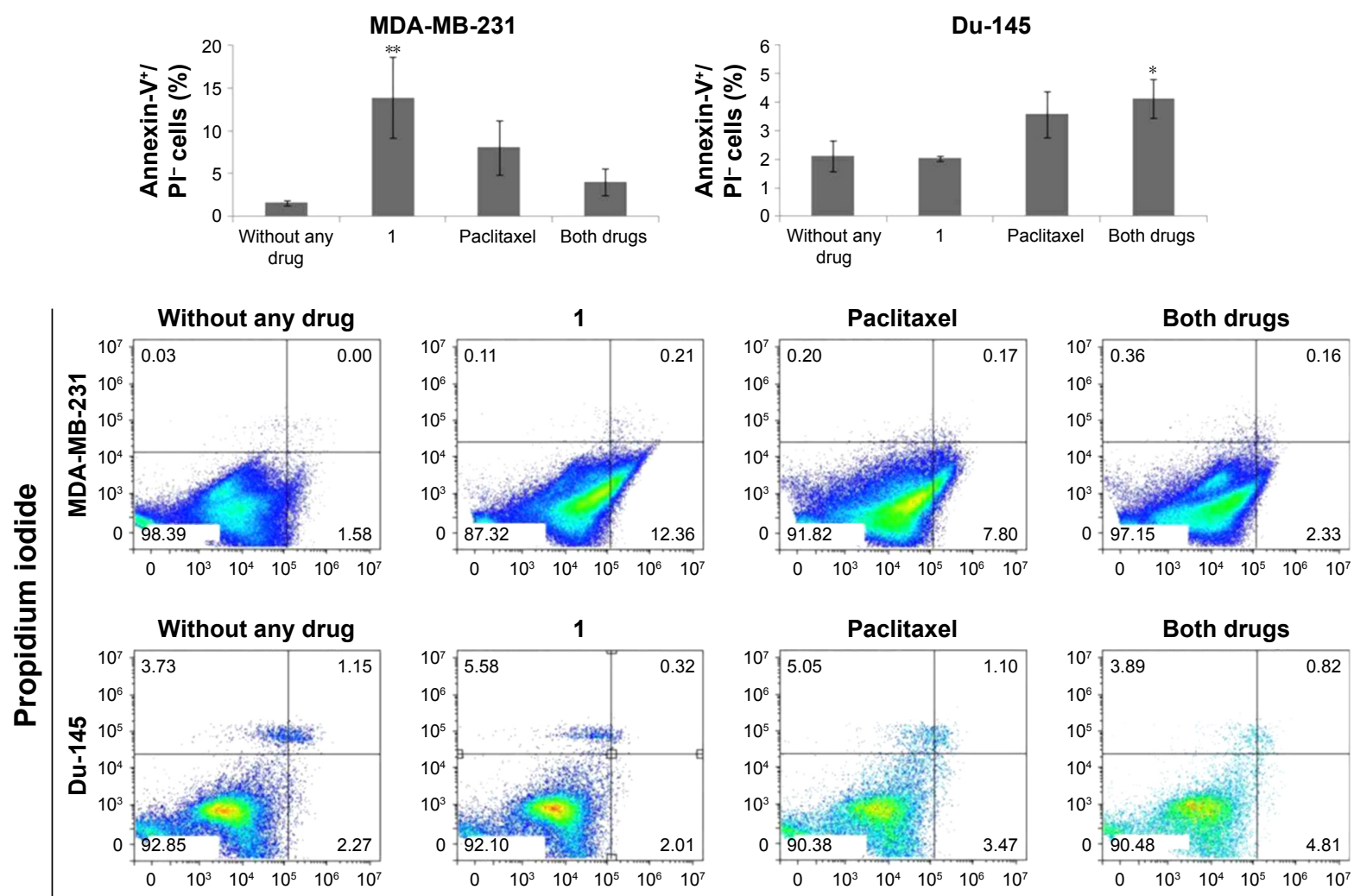

Annexin-V

Figure 3 Apoptosis after drug treatment.

Notes: Apoptosis after treatment with $2 \mu \mathrm{M}$ compound I combined with 40 or $12 \mathrm{nM}$ paclitaxel, in duration of $48 \mathrm{~h}$ in MDA-MB-23I or Du- 145 cell lines, respectively. Data represent the mean $\pm \mathrm{SD}$ of Annexin $\mathrm{V}^{+} / \mathrm{PI}^{-}$cells. Columns, mean of cells; bars, $\mathrm{SD} ; * \mathrm{P}<0.05$ and $* * P<0.01$.

Abbreviation: SD, standard deviation.

Du-145 early apoptotic cells was not changed after treatment with compound $\mathbf{1}$, and it was only slightly enhanced after paclitaxel treatment. The combination of both drugs, however, significantly enhanced the percentage of early apoptotic cells compared with non-treated Du-145 cells. The percentage of Du-145 apoptotic cells was decreased after treatment with compound 1. The percentage of Du-145 necrotic cells was increased after treatment with compound $\mathbf{1}$, as well as after treatment with paclitaxel. The percentage of MDA-MB-231 early apoptotic cells was three times higher after combined treatment compared with non-treated MDA-MB-231 cells. Possible antagonistic effects of compound $\mathbf{1}$ and paclitaxel in modulating apoptosis could be caused by changed glycosphingolipid GM3 expression after PLC inhibitor treatment as will be discussed. The percentage of MDA-MB-231 necrotic cells was not so affected by different treatments.

\section{Compound I leads to a decrease in number of breast CSCs}

In breast and prostate cancer cell lines, such as MDA-MB-231 and Du-145, a subset of markers, including CD44 ${ }^{+}$CD24- has been shown to enrich CSCs. ${ }^{1,2}$ To investigate whether compound 1 could influence the phenotypic profile of cancer cell subpopulations, expression of CD44 and CD24 surface markers was evaluated in cells treated with $2 \mu \mathrm{M}$ compound 1 and/or paclitaxel ( $40 \mathrm{nM}$ for breast and $12 \mathrm{nM}$ for prostate cancer cells). Treatment with compound $\mathbf{1}$ alone shows slight, but statistically significant decrease in the $\mathrm{CD}_{4} 4^{+} / \mathrm{CD} 24^{-}$subpopulation from $99.09 \% \pm 0.53 \%$ (untreated control) to $96.78 \% \pm 1.03 \%$ in MDA-MB-231 cell culture. Paclitaxel caused non-significant increase in CSCs percentage in both cell lines as compared with the control. Our finding of increased CSCs percentage after paclitaxel alone treatment corresponds to finding by others. ${ }^{26} \mathrm{Com}-$ bined treatment with paclitaxel and compound 1 abolished the effect of compound $\mathbf{1}$ in reducing CSCs with paclitaxel increasing CSCs more efficiently than the decrease induced by compound $\mathbf{1}$. The same subpopulation was significantly increased in Du-145 cell culture (Figure 4). A combination of both drugs only significantly changed the Du-145 cells to higher percentage of CSCs. 


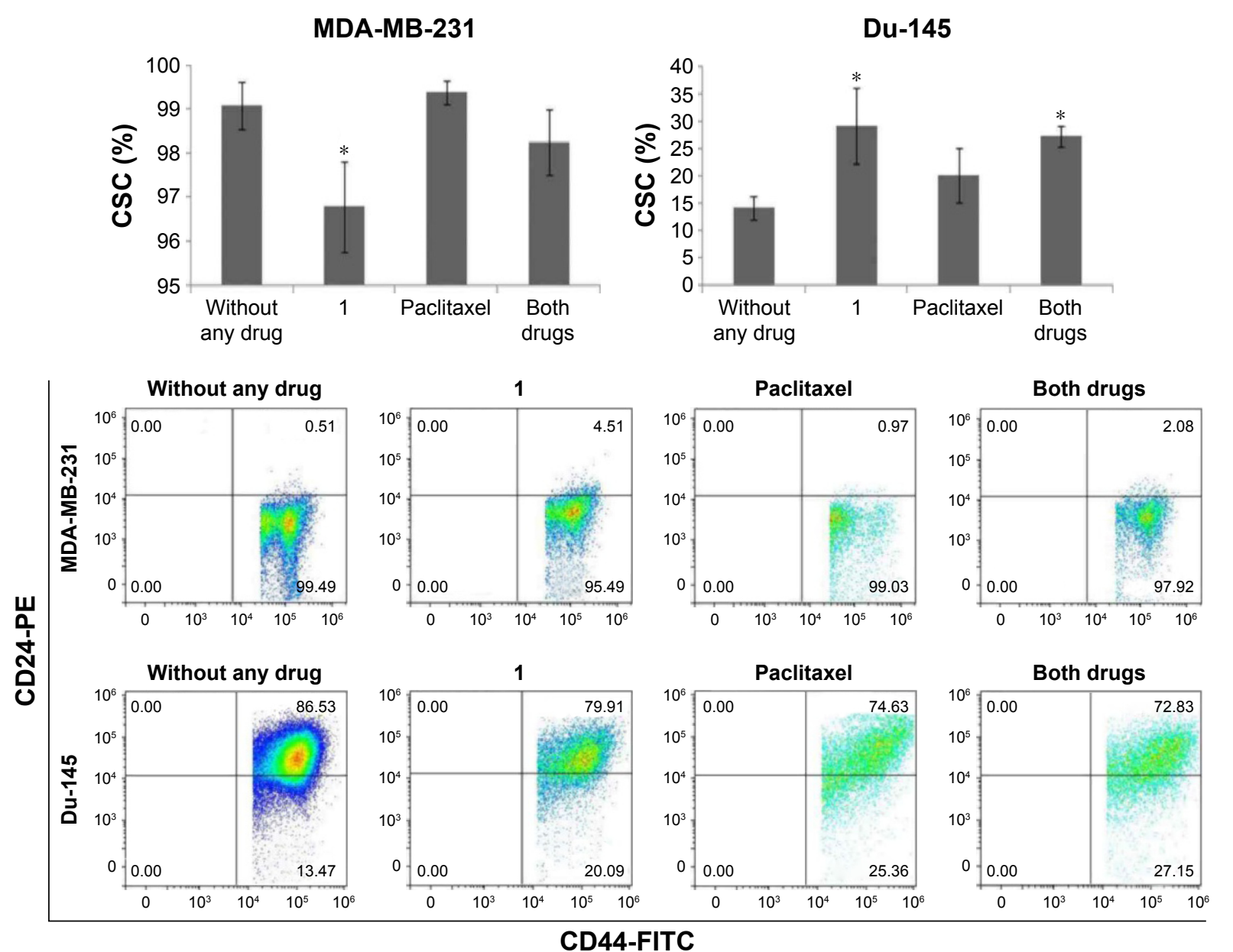

Figure 4 CSC $\left(\mathrm{CD}_{4} 4^{+} / \mathrm{CD} 24^{-}\right)$after drug treatment.

Notes: Percentage of CSCs after treatment with $2 \mu \mathrm{M}$ compound I combined with 40 or $12 \mathrm{nM}$ paclitaxel, in duration of $48 \mathrm{~h}$ in MDA-MB-23I or Du-I45 cell lines, respectively. Data represent the mean $\pm S D$. Columns, mean of cells; bars, $S D ; * P<0.05$.

Abbreviations: CSCs, cancer stem cells; SD, standard deviation.

\section{Compound I increases GM3 expression of breast CSCs and lowers percentage of prostate $\mathrm{GM3}^{+} \mathrm{CSC}$ subpopulation}

GM3 ganglioside expression was studied in CSCs with the aim to check whether the cytotoxic effects of compound $\mathbf{1}$ are mediated via GM3 membrane content. GM3 GMI (GM3 expression/cell) was increased in CSC MDA-MB-231 cells after treatment with compound 1, whereas GM3 GMI of CSC Du-145 was unaffected (Figure 5A and B). However, compound 1 did not influence the percentage of $\mathrm{GM}^{+} \mathrm{MDA}-\mathrm{MB}-$ $231 \mathrm{CSC}$ sut, alone, as well as in combination with paclitaxel, it lowered the percentage of Du-145 GM3 ${ }^{+}$CSCs (Figure 6).

\section{Compound I does not influence CDI5s expression but it lowers the percentage of $\mathrm{CDI} 5 \mathrm{~s}^{+} \mathrm{CSCs}$ in both cell lines}

$\mathrm{CD} 15 \mathrm{~s}$ enables malignant infiltration in different tissues; therefore, the impact of compound $\mathbf{1}$ on CD15s expression was tested. Treatment with compound $\mathbf{1}$ did not influence CD15s expression on CSCs of both cell lines (Figure 5C and D). The percentage of MDA-MB-231 and Du-145 CD15 $\mathrm{s}^{+}$CSCs was lowered in case of treatment with compound 1 while combined treatment decreased the percentage of Du-145 CD15s ${ }^{+}$CSCs (Figure S1).

\section{Discussion}

Aberrant glycosylation can increase cancer cell metastatic ability. ${ }^{27}$ The focus of our interest was GM3 and CD15s glycoconjugate expression on the surface of CSCs that are responsible for tumor relapse and resistance to therapy. We found that newly synthesized putative PLC inhibitor, 3-amino-5-oxo- $N$-naphthyl-5,6,7,8-tetrahydrothieno[2,3-b] quinoline-2-carboxamide (compound 1; Figure 1) was cytotoxic for both breast MDA-MB-231 and prostate Du-145 cancer cells. Tenfold difference in $\mathrm{IC}_{50}$ value for MDA-MB231 cell line is due to the fact that thymidine uptake assay 

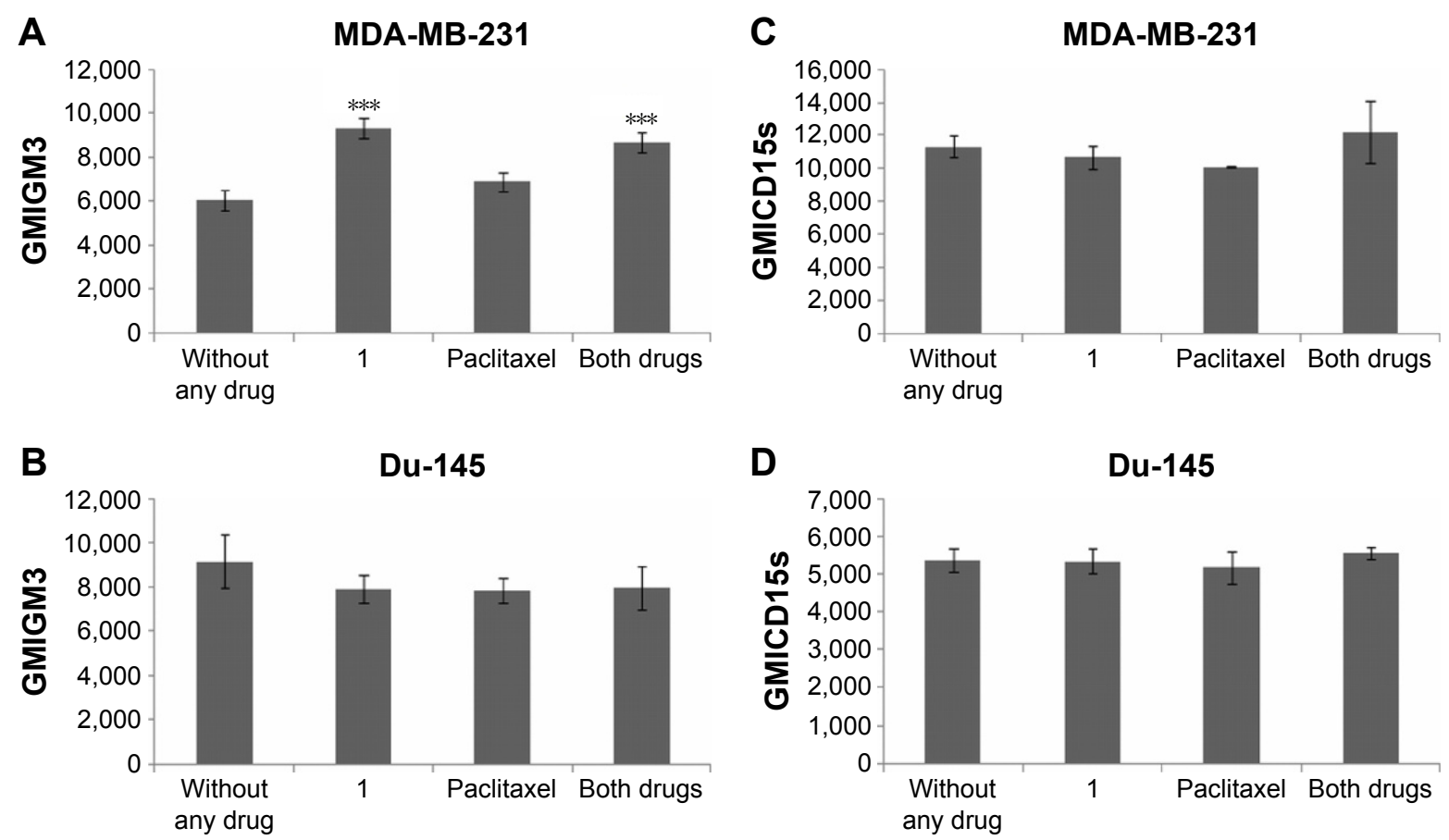

Figure 5 GM3 and CDI5s geometric mean fluorescence of CSC after drug treatment.

Notes: GM3 and CDI5s geometric mean fluorescence of CSC after treatment with $2 \mu$ M compound I combined with 40 or $12 \mathrm{nM}$ paclitaxel, in duration of $48 \mathrm{~h}$ in MDAMB-23I (A, C) or Du-I45 (B, D) cell lines, respectively. Data represent the mean \pm SD. Columns, mean of viable cells; bars, SD; $* * * P<0.00$ I.

Abbreviations: CSCs, cancer stem cells; GMI, geometric mean fluorescence intensity; SD, standard deviation.

measures thymidine incorporation into the DNA where cell division is active. MTT assay used in our experiment measures viable cells regardless whether the cells are undergoing active cell division or not. As the compound may be a cytostatic drug that induced cells to a $\mathrm{G} 2 / \mathrm{M}$ phase cell cycle arrest, the discrepancy in the $\mathrm{IC}_{50}$ measured is likely to be contributed by the different methods of analysis.

Determination of the type of cell death showed that compound 1-induced cell death of breast CSCs occurred mainly by apoptosis. In addition, breast cell population showed a lower percentage of CSC subpopulation, unchanged percentage of $\mathrm{GM}^{+}{ }^{+} \mathrm{CSC}$ subpopulation, while GM3 expression/ CSC was significantly increased. However, the extent of prostate CSC apoptosis and GM3 expression/CSC was not significantly changed after treatment with compound 1 . CSC subpopulation percentage in total prostate cell population was significantly increased while the percentage of the GM3 ${ }^{+}$ prostate CSC subpopulation was significantly decreased. Therefore, it can be assumed that the increase in apoptosis and lowered percentage of CSC subpopulation are mediated by increased GM3 expression on MDA-MB-231 CSCs. This assumption is in accordance with a recent finding that GM3 mediates cisplatin-induced apoptosis in human colon cancer cells. ${ }^{28}$ GM3 is known to inhibit tyrosine kinases associated with epidermal and fibroblast growth factor receptors (EGF and FGF receptors). ${ }^{29,30}$ EGF receptor is functional in prostate Du-145 cells, ${ }^{31}$ while breast MDA-MB-231 cells express EGF receptor but lack a proliferative response to $\mathrm{EGF}^{32}$ Both cell lines possess FGF receptors. When human embryonic fibroblasts adhere, they give rise to signaling to activate FGF receptor through tyrosine phosphorylation and inducing cell proliferation under serum-free conditions without FGF addition. ${ }^{33}$ FGF can increase PLC- $\delta$ activity and enhance cell proliferation. ${ }^{34}$ Cell lines in this study were grown in $10 \%$ fetal bovine serum and ordinary FGF signaling was expected to happen. Among the PLC isozymes, primary PLCs, PLC $-\beta$ and PLC- $\gamma$ are directly activated by receptor activation, unlike other secondary PLCs (PLC- $\varepsilon$, PLC- $\delta 1$ and PLC- $\eta 1) .{ }^{35}$ The PLC- $\delta$ is the most important among all PLCs. Loss of function in PLC- $\delta$ gene-deficient mice has revealed the critical function of PLC isozymes as a key molecule of cellular functions. ${ }^{36}$ Receptor-mediated $\operatorname{PLC}(\beta$ and/or $\gamma$ ) activation is usually transient and rapidly desensitized, while the positive $\mathrm{Ca}^{2+}$-inositol phospholipid loop, that activates PLC- $\delta 1$, could prolong the action of receptor-activated PLC and may operate in slower or more prolonged cellular responses. ${ }^{37}$ PLC- $\beta$ isozymes are activated by G-protein-coupled receptor and PLC- $\gamma$ isozymes are activated by receptor tyrosine kinase as it is an FGF receptor. ${ }^{35}$ We can assume that FGF produces short transient activation of PLC- $\gamma$ in our MDA-MB-231 cell line experiment. Due to action of inhibitor 1 treatment, calcium released after PLC- $\gamma$ 

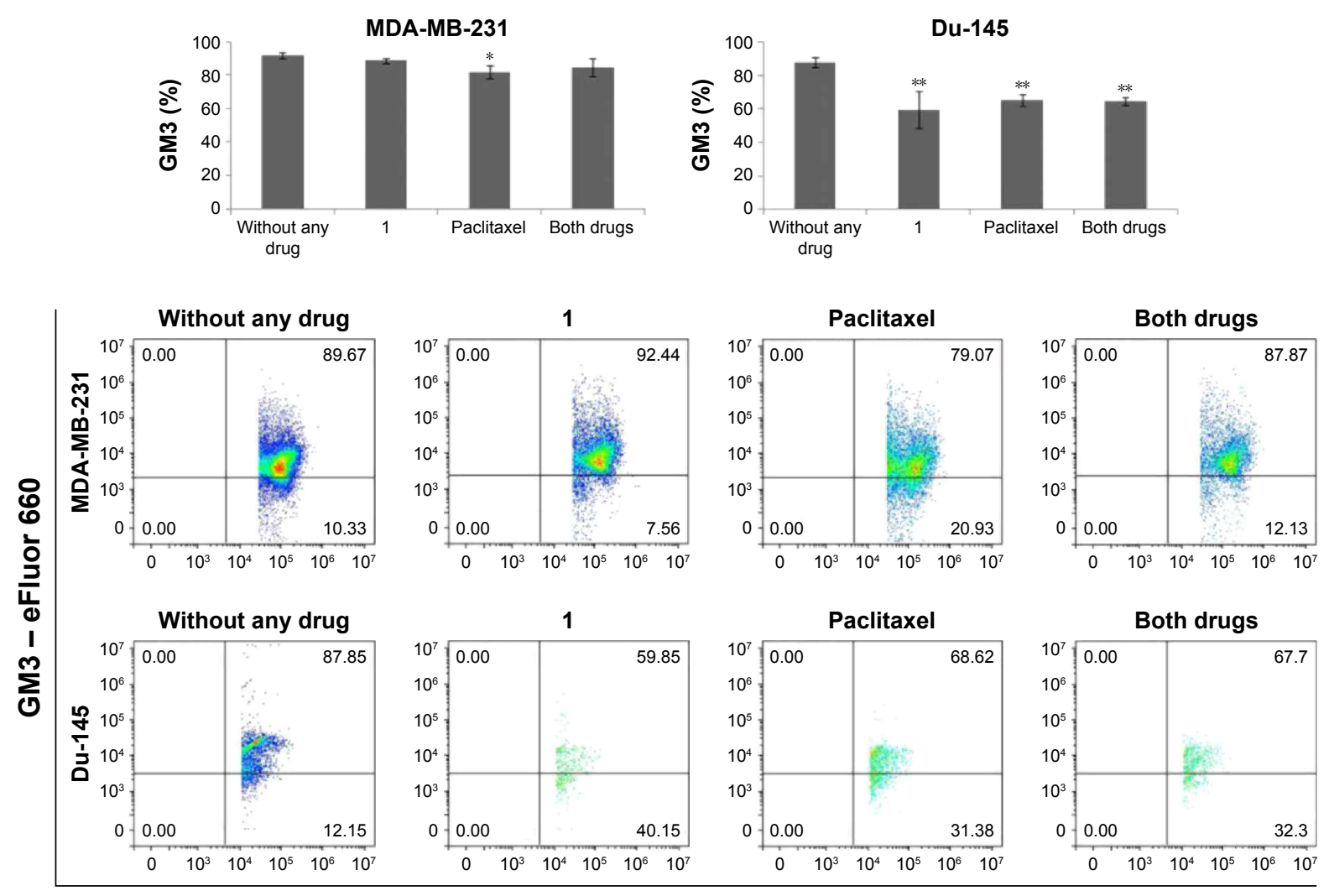

CD44-FITC

Figure 6 Percentage of $\mathrm{GM}^{+} \mathrm{CSC}$ s after drug treatment.

Notes: Percentage of GM3 ${ }^{+}$CSC after treatment with $2 \mu \mathrm{M}$ compound I combined with 40 or I $2 \mathrm{nM}$ paclitaxel, in duration of $48 \mathrm{~h}$ in MDA-MB-23I or Du-I45 cell lines, respectively. Data represent the mean $\pm S D$. Columns, mean of cells; bars, $S D ; * P<0.05$ and $* * P<0.01$.

Abbreviations: CSCs, cancer stem cells; SD, standard deviation.

action cannot induce prolonged PLC- $\delta 1$ activity, resulting in lower cell proliferation.

The lack of the same response of Du- 145 cells to the PLC inhibitor (unchanged apoptosis and increased CSC percentage) might be regulated through PLC, protein kinase C (PKC) and EGF receptor interactions. Wells et al hypothesized that luteinizing hormone-releasing hormone triggers PLC to activate PKC, and PKC activation limits EGF receptor tyrosine kinase activity by phosphorylating EGF receptor at threonine 654 in Du-145 cells. ${ }^{31}$ Further experiments will resolve whether the difference in response to compound 1 between Du-145 cells and MDA-MB-231 is due to their known difference in EGF receptor response. ${ }^{31,32}$

Enhanced GM3 expression per each CSC in the MDAMB-231 cell line experiment could inhibit cell proliferation by blocking FGF receptor phosphorylation. Anti-GM3 antibody used in this study was developed against GM3 AntiGM3 antibody used in this study was developed against GM3 substituted with $\mathrm{N}$-acetyl neuraminic acid -GM3(NeuAc). Resorcinol thin-layer chromatography staining of total MDA-MB-231 cell ganglioside extract detected GM3
(NeuAc) as the major ganglioside fraction. ${ }^{6}$ Authors have not used GM3 (NeuGc) standard, but the fraction clearly visible on published chromatogram below GM3 (NeuAc) can be GM3 (NeuGc) or GM3 (NeuAc) with shorter fatty acid or sphingosine hydrophobic chain. ${ }^{6}$ GM3 (NeuGc) is chromatographed below GM3 (NeuAc) due to higher affinity to hydrophilic silica-gel stationary phase and lower affinity to hydrophobic mobile phase ${ }^{38}$ It is important to distinguish GM3 (NeuAc) and GM3 (NeuGc) ganglioside fractions, the latter leading to more malignant phenotype. ${ }^{8}$ Overexpression or neo-expression of gangliosides in breast cancer has been usually demonstrated. GM3 (NeuGc) has been detected in invasive ductal carcinomas, with $100 \%$ efficiency in primary tumors for women diagnosed with stage II breast cancer. ${ }^{39}$ Neu $5 \mathrm{Gc}$ is not present in humans because the gene encoding the CMP-Neu5Ac hydroxylase is irreversibly inactivated. The absence of the enzyme responsible for the conversion of CMP-Neu5Ac to CMP-Neu5Gc leads to the total absence of Neu5Gc in healthy human tissues. However, Neu5Gc was shown to be expressed on glycoproteins and gangliosides in breast cancers. ${ }^{39}$ 
Using resorcinol staining of thin-layer chromatogram, GM3 was detected in total Du-145 cell ganglioside extract as the minor fraction. ${ }^{7}$ Treatment with compound 1 resulted in an unchanged GM3 expression/Du-145 CSC in comparison to control cells. GM3 is the minor ganglioside fraction of Du-145 cells ${ }^{7}$ and probable induction of GM3 synthesis, due to PLC inhibition, could result in increased conversion to GD1a, the major Du-145 ganglioside fraction. On the contrary, the same mechanism in MDA-MB-231 cells would result in higher expression of the GM3, its major ganglioside fraction $^{6}$ as was found in this study.

In addition to GM3, we analyzed CD15s glycoconjugate, the major ligand of endothelial (E) selectin, responsible for cancer cell metastasizing. In the case of CD15s glycosphingolipid, [NeuAc-Gal-(Fuc)-GlcNAc] glycoantigen is linked to a ceramide anchor in the outer leaflet of the plasma membrane. In the case of CD15s glycoprotein, the same glycoantigen is linked to CD11b or CD44 transmembrane glycoprotein. ${ }^{40} \mathrm{CD} 44$ variant isoform 4 (CD44v4) is a major metastatic MDA-MB-231 glycoprotein decorated with CD15s moieties and serves as an E-selectin ligand in facilitating tumor cell metastasis. ${ }^{41}$ It was shown that tumor spheroid/aggregate grown MDA-MB-231 unregulated their CD15s expression and demonstrate the most robust rolling behavior on E-selectin-coated surfaces, compared with MDA-MB-231 cells from plasma and cytokine treatments. ${ }^{42}$ In this study, CD15s expression per one CSC was not changed while the percentage of CD $15 \mathrm{~s}^{+} \mathrm{CSCs}$ was lower in both cell lines after treatment with compound $\mathbf{1}$. That means, a lower percentage of CSCs possesses metastatic potential after PLC inhibition. Similarly, the beneficial effect of paclitaxel treatment was lowering of CD15 $\mathrm{s}^{+}$CSCs in both cell lines but this effect was weaker in comparison to treatment with compound $\mathbf{1}$.

The beneficial effect of treatment with both drugs $(\mathbf{1}+$ paclitaxel) is increased GM3 expression/CSC in MDAMB-231 cells. This increase was weaker in comparison with the effect of treatment with compound $\mathbf{1}$ alone. In MDAMB-231 cell line, paclitaxel in combination with higher concentrations of compound $\mathbf{1}$ showed antagonistic effect, that is, increased cell survival. There are no data in literature on paclitaxel influence upon GM3 expression, but there is the evidence about GM3 attenuation of paclitaxel-triggered apoptosis in ovarian cancer cells. ${ }^{43}$ Our finding of decreased apoptosis after combined drug treatment in MDA-MB-231 cell line is in accordance with this reference. ${ }^{43}$

Furthermore, determinations of apoptosis and CSCs after treatment with a combination of compound $\mathbf{1}$ and paclitaxel gave ambiguous results for androgen-independent prostate cancer cells. The apoptosis of Du-145 cells was increased after treatment with both drugs, but the percentage of CSCs was higher after combined drug treatment. More types of experiments should be performed to clarify the effect of combined compound $\mathbf{1}$ and paclitaxel treatment.

We demonstrated that treatment of human MDA-MB231 triple-negative breast cancer cells with derivative $\mathbf{1}$ resulted in higher apoptosis and GM3 expression/CSC, and lower percentages of CSC subpopulation and CD15 $\mathrm{s}^{+} \mathrm{CSCs}$. Considering that triple-negative breast cancers are characterized by an increased percentage of breast CSCs and knowing their association with an increased risk of metastasis and mortality, compound $\mathbf{1}$ deserves attention as a potential new drug for triple-negative breast cancer therapy.

\section{Acknowledgments}

Data shown resulted from scientific project "Pathobiochemistry of glycosphingolipid antigens" and institutional science financing, which was supported by Ministry of Science, Education and Sports, Republic of Croatia. Additional financial support was provided by the Auckland Medical Research Fund, New Zealand.

We are sincerely indebted to Drs Ashley E. Ross (The James Buchanan Brady Urological Institute and Department of Urology, Johns Hopkins University School of Medicine, Baltimore, MD, USA) and Inga Reynissdóttir (Cell Biology Unit, Department of Pathology, Landspítali University Hospital, Reykjavík, Iceland) for their critical reading of manuscript.

\section{Disclosure}

The authors report no conflicts of interest in this work.

\section{References}

1. May CD, Sphyris N, Evans KW, Werden SJ, Guo W, Mani SA. Epithelial-mesenchymal transition and cancer stem cells: a dangerously dynamic duo in breast cancer progression. Breast Cancer Res. 2011; 13(1):202

2. Castillo V, Valenzuela R, Huidobro C, Contreras HR, Castellon EA Functional characteristics of cancer stem cells and their role in drug resistance of prostate cancer. Int J Oncol. 2014;45(3):985-994.

3. Al-Hajj M, Wicha MS, Benito-Hernandez A, Morrison SJ, Clarke MF. Prospective identification of tumorigenic breast cancer cells. Proc Natl Acad Sci U S A. 2003;100(7):3983-3988.

4. Llombart-Cussac A, Bermejo B, Villanueva C, et al. SOLTI NeoPARP: a phase II randomized study of two schedules of iniparib plus paclitaxel versus paclitaxel alone as neoadjuvant therapy in patients with triple-negative breast cancer. Breast Cancer Res Treat. 2015;154(2): 351-357.

5. Corcoran C, Rani S, O'Brien K, et al. Docetaxel-resistance in prostate cancer: evaluating associated phenotypic changes and potential for resistance transfer via exosomes. PLoS One. 2012;7(12):e50999. 
6. Nohara K, Wang F, Spiegel S. Glycosphingolipid composition of MDAMB-231 and MCF-7 human breast cancer cell lines. Breast Cancer Res Treat. 1998;48(2):149-157.

7. Ravindranath MH, Muthugounder S, Presser N, Ye X, Brosman S, Morton DL. Endogenous immune response to gangliosides in patients with confined prostate cancer. Int J Cancer. 2005;116(3):368-377.

8. Oliva JP, Valdes Z, Casaco A, et al. Clinical evidences of GM3 (NeuGc) ganglioside expression in human breast cancer using the 14F7 monoclonal antibody labelled with $(99 \mathrm{~m}) \mathrm{Tc}$. Breast Cancer Res Treat. 2006; 96(2):115-121.

9. Prokazova NV, Samovilova NN, Gracheva EV, Golovanova NK. Ganglioside GM3 and its biological functions. Biochemistry (Mosc). 2009;74(3):235-249.

10. Dykstra M, Cherukuri A, Sohn HW, Tzeng SJ, Pierce SK. Location is everything: lipid rafts and immune cell signaling. Anпu Rev Immunol. 2003;21:457-481.

11. Neame SJ, Uff CR, Sheikh H, Wheatley SC, Isacke CM. CD44 exhibits a cell type dependent interaction with triton $\mathrm{X}-100$ insoluble, lipid rich, plasma membrane domains. J Cell Sci. 1995;108(Pt 9):3127-3135.

12. Kiely JM, Hu Y, Garcia-Cardena G, Gimbrone MA Jr. Lipid raft localization of cell surface E-selectin is required for ligation-induced activation of phospholipase C gamma. J Immunol. 2003;171(6):3216-3224.

13. Barthel SR, Gavino JD, Descheny L, Dimitroff CJ. Targeting selectins and selectin ligands in inflammation and cancer. Expert Opin Ther Targets. 2007;11(11):1473-1491.

14. Babina IS, McSherry EA, Donatello S, Hill AD, Hopkins AM. A novel mechanism of regulating breast cancer cell migration via palmitoylationdependent alterations in the lipid raft affiliation of CD44. Breast Cancer Res. 2014;16(1):R19.

15. Tagami S, Inokuchi Ji J, Kabayama K, et al. Ganglioside GM3 participates in the pathological conditions of insulin resistance. $J$ Biol Chem. 2002;277(5):3085-3092.

16. Leung E, Hung JM, Barker D, Reynisson J. The effect of a thieno[2,3-b] pyridine PLC-[gamma] inhibitor on the proliferation, morphology, migration and cell cycle of breast cancer cells. MedChem Comm. 2014; 5(1):99-106.

17. Feng L, Reynisdottir I, Reynisson J. The effect of PLC-gamma2 inhibitors on the growth of human tumour cells. Eur J Med Chem. 2012;54: 463-469.

18. Hung JM, Arabshahi HJ, Leung E, Reynisson J, Barker D. Synthesis and cytotoxicity of thieno[2,3-b]pyridine and furo[2,3-b]pyridine derivatives. Eur J Med Chem. 2014;86:420-437.

19. Arabshahi HJ, Leung E, Barker D, Reynisson J. The development of thieno[2,3-b]pyridine analogues as anticancer agents applying in silico methods. MedChem Comm. 2014;5(2):186-191.

20. Reynisson J, Court W, O'Neill C, et al. The identification of novel PLC- $\gamma$ inhibitors using virtual high throughput screening. Bioorg Med Chem. 2009;17(8):3169-3176.

21. Reynisson J, Jaiswal JK, Barker D, et al. Evidence that phospholipase C is involved in the antitumour action of NSC768313, a new thieno[2,3-b] pyridine derivative. Cancer Cell Int. 2016;16:18.

22. Arabshahi HJ, van Rensburg M, Pilkington LI, et al. A synthesis, in silico, in vitro and in vivo study of thieno[2,3-b]pyridine anticancer analogues. MedChem Comm. 2015;6(11):1987-1997.

23. Mosmann T. Rapid colorimetric assay for cellular growth and survival: application to proliferation and cytotoxicity assays. J Immunol Methods. 1983;65(1-2):55-63.

24. Ross AE, Emadi A, Marchionni L, et al. Dimeric naphthoquinones, a novel class of compounds with prostate cancer cytotoxicity. BJU Int. 2011;108(3):447-454.

25. Yang MY, Wang CJ, Chen NF, Ho WH, Lu FJ, Tseng TH. Luteolin enhances paclitaxel-induced apoptosis in human breast cancer MDA-MB231 cells by blocking STAT3. Chem Biol Interact. 2014;213:60-68.
26. Park SY, Kim MJ, Park SA, et al. Combinatorial TGF-beta attenuation with paclitaxel inhibits the epithelial-to-mesenchymal transition and breast cancer stem-like cells. Oncotarget. 2015;6(35):37526-37543.

27. Handa K, Hakomori SI. Carbohydrate to carbohydrate interaction in development process and cancer progression. Glycoconj J. 2012;29(8-9): 627-637.

28. Chung TW, Choi HJ, Kim SJ, et al. The ganglioside GM3 is associated with cisplatin-induced apoptosis in human colon cancer cells. PLoS One. 2014;9(5):e92786.

29. Bremer EG, Schlessinger J, Hakomori S. Ganglioside-mediated modulation of cell growth. Specific effects of GM3 on tyrosine phosphorylation of the epidermal growth factor receptor. J Biol Chem. 1986;261(5):2434-2440.

30. Toledo MS, Suzuki E, Handa K, Hakomori S. Cell growth regulation through GM3-enriched microdomain (glycosynapse) in human lung embryonal fibroblast WI38 and its oncogenic transformant VA13. J Biol Chem. 2004;279(33):34655-34664.

31. Wells A, Souto JC, Solava J, Kassis J, Bailey KJ, Turner T. Luteinizing hormone-releasing hormone agonist limits DU-145 prostate cancer growth by attenuating epidermal growth factor receptor signaling. Clin Cancer Res. 2002;8(4):1251-1257.

32. Davidson NE, Gelmann EP, Lippman ME, Dickson RB. Epidermal growth factor receptor gene expression in estrogen receptor-positive and negative human breast cancer cell lines. Mol Endocrinol. 1987; 1(3):216-223.

33. Toledo MS, Suzuki E, Handa K, Hakomori S. Effect of ganglioside and tetraspanins in microdomains on interaction of integrins with fibroblast growth factor receptor. J Biol Chem. 2005;280(16):16227-16234.

34. Mi LY, Ettenson DS, Edelman ER. Phospholipase C-delta extends intercellular signalling range and responses to injury-released growth factors in non-excitable cells. Cell Prolif. 2008;41(4):671-690.

35. Yang YR, Follo MY, Cocco L, Suh PG. The physiological roles of primary phospholipase C. Adv Biol Regul. 2013;53(3):232-241.

36. Suh PG, Park JI, Manzoli L, et al. Multiple roles of phosphoinositidespecific phospholipase C isozymes. BMB Rep. 2008;41(6):415-434.

37. Lomasney JW, Cheng HF, Kobayashi M, King K. Structural basis for calcium and phosphatidylserine regulation of phospholipase $\mathrm{C}$ delta1. Biochemistry. 2012;51(11):2246-2257.

38. Markotic A, Culic VC, Kurir TT, et al. Oxygenation alters ganglioside expression in rat liver following partial hepatectomy. Biochem Biophys Res Commun. 2005;330(1):131-141.

39. Cazet A, Julien S, Bobowski M, Burchell J, Delannoy P. Tumourassociated carbohydrate antigens in breast cancer. Breast Cancer Res. 2010;12(3):204

40. Zen K, Cui LB, Zhang CY, Liu Y. Critical role of mac-1 sialyl Lewis $\mathrm{x}$ moieties in regulating neutrophil degranulation and transmigration. J Mol Biol. 2007;374(1):54-63.

41. Zen K, Liu DQ, Guo YL, et al. CD44v4 is a major E-selectin ligand that mediates breast cancer cell transendothelial migration. PLoS One. 2008;3(3):e1826.

42. Geng Y, Chandrasekaran S, Hsu JW, Gidwani M, Hughes AD, King MR. Phenotypic switch in blood: effects of pro-inflammatory cytokines on breast cancer cell aggregation and adhesion. PLoS One. 2013;8(1):e54959.

43. Huang S, Bijangi-Vishehsaraei K, Saadatzadeh MR, Safa AR. Human GM3 synthase attenuates axol-triggered apoptosis associated with downregulation of caspase-3 in ovarian cancer cells. $J$ Cancer Ther. 2012;3(5):504-510. 


\section{Supplementary materials}

Table SI Diluted antibodies

\begin{tabular}{ll}
\hline Antibody & Original antibody:PBS \\
\hline Anti-CDI5s & $1: 3$ \\
efluor 660 fluorochrome & $1: 10$ \\
Anti-CD24-PE & $1: 3$ \\
Anti-CD44-FITC & $1: 13$ \\
Anti-GM3 & $1: 4$ \\
\hline
\end{tabular}

Note: Antibodies were diluted in PBS.

Abbreviation: PBS, phosphate-buffered saline.
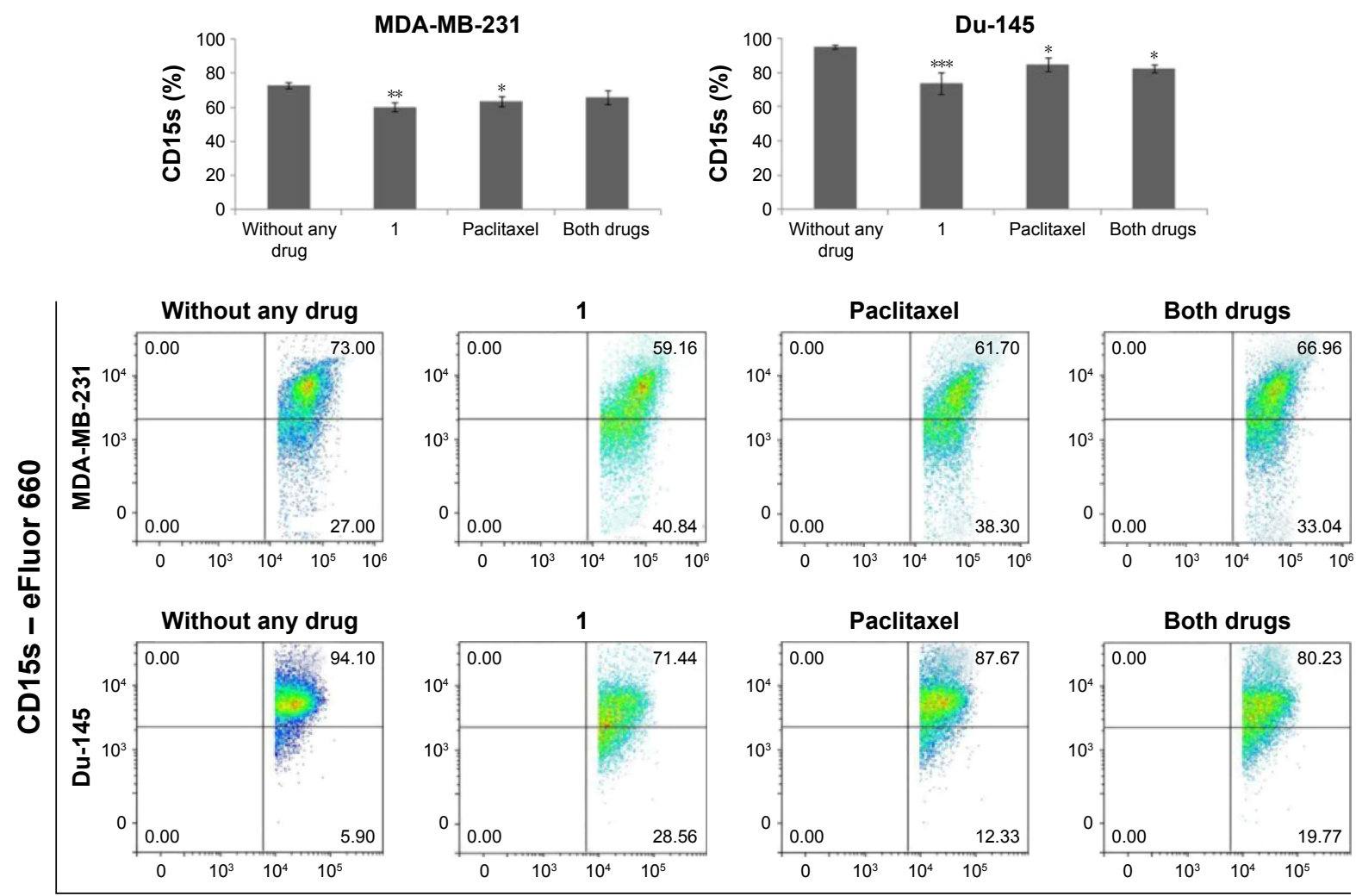

CD44-FITC

Figure SI Percentage of CDI5s+ CSCs after drug treatment.

Notes: Percentage of CDI5s $\mathrm{s}^{+}$CSCs after treatment with $2 \mu \mathrm{M}$ compound I combined with 40 or $12 \mathrm{nM}$ paclitaxel, in duration of $48 \mathrm{~h}$ in MDA-MB-23I or Du- 145 cell lines, respectively. Data represent the mean $\pm S D$. Columns, mean of cells; bars, $S D ; * P<0.05, * * P<0.01$ and $* * * P<0.001$.

Abbreviations: CSCs, cancer stem cells; SD, standard deviation.

\section{Publish your work in this journal}

Drug Design, Development and Therapy is an international, peerreviewed open-access journal that spans the spectrum of drug design and development through to clinical applications. Clinical outcomes, patient safety, and programs for the development and effective, safe, and sustained use of medicines are the features of the journal, which has also been accepted for indexing on PubMed Central. The manuscript management system is completely online and includes a very quick and fair peer-review system, which is all easy to use. Visit http://www.dovepress.com/testimonials.php to read real quotes from published authors. 